\title{
POTENTIAL DUAL MECHANISM OF HYPOURICEMIC ACTIVITY OF DPP-4 INHIBITORS WITH PURINE-BASED SCAFFOLD
}

\author{
Katarina Tomović1 ${ }^{\text {, Gordana Kocić2 }}$, Andrija Šmelcerović ${ }^{3}$
}

\begin{abstract}
Dipeptidyl peptidase-4 (DPP-4) binds to adenosine deaminase (ADA) and form a complex which catalyzes an irreversible deamination of extracellular adenosine to inosine, what leads to the generation of hypoxanthine, xanthine and finally uric acid by xanthine oxidase (XO) in purine catabolism with the production of reactive oxygen species. Xanthine-based DPP-4 inhibitor linagliptin showed inhibitory potential on XO. It exerts a hypouricemic effect by inhibiting DPP-4 activity and its binding to ADA, what causes the increase of adenosine and decrease of XO substrates levels, as well as by inhibiting XO activity. Based on the evidenced dual mechanism of hypouricemic activity of linagliptin, the possibility of other DPP-4 inhibitors with the purine-based scaffold to act in the same manner exists.
\end{abstract}

Acta Medica Medianae 2019;58(1):50-63.

Key words: dipeptidyl peptidase-4, xanthine oxidase, adenosine deaminase

\footnotetext{
${ }^{1}$ University of Niš, Faculty of Medicine, Department of Pharmacy, Niš, Serbia

${ }^{2}$ University of Niš, Faculty of Medicine, Institute of Biochemistry, Niš, Serbia

${ }^{3}$ University of Niš, Faculty of Medicine, Department of Chemistry, Niš, Serbia
}

Contact: Andrija Šmelcerović

Bulevard dr Zoran Djindjić 81, 18000, Niš, Serbia

E-mail: a.smelcerovic@yahoo.com

\section{Introduction}

Chronic hyperuricemia represents a risk factor for metabolic syndrome, cardiovascular and renal disorders (1-6). Although the elevation of uric acid levels acts as a risk factor and contributes to the development of mentioned disorders, it also represents a marker and consequence in cardiovascular and renal pathology (7). Hyperuricemia and oxidative stress generated via xanthine oxidase $(\mathrm{XO})$ activity promote endothelial dysfunction. Uric acid stimulates proliferation of vascular smooth muscle cells, elevates levels of inflammatory markers including C-reactive protein and tumor necrosis factor-a, nuclear factor kappa $B$, monocyte chemoattractant protein-1, interleukin- $1 \beta$ and -6 . Improvement might be associated with the administration of urate-lowering agents such as XO inhibitors $(1,3-6)$.

It has been shown in isolated postischemic rat heart that XO mediated generation of free radicals upon reperfusion is triggered by enhancement of for50 mation of its substrates, hypoxanthine, and xanthine, during ischemia, while alterations in the enzyme activity are not sufficient as major limiting factor. During ischemia, the accumulation of hypoxanthine and xanthine occurs via degradation of adenosine triphosphate (ATP) to adenosine monophosphate (AMP), adenosine and inosine. Since substrates availability is significant in the production of free radicals and consequently in the determination of severity in postischemic injury, the decrease of their formation might offer novel therapeutic approach besides the inhibition of XO activity, with beneficial effect in terms of the increase of adenosine levels as well as the preservation of high energy phosphates (8). Moreover, it has been shown in postischemic rat heart that reduction of $\mathrm{XO}$ substrate generation by inhibition of adenosine deaminase (ADA) activity can prevent the production of free radicals and contractile dysfunction (9).

Dipeptidyl peptidase-4 (DPP-4) is ADA binding protein, with which in complex it contributes to T-cell stimulation and proliferation $(10,11)$. Bimolecular complex of DPP-4 and ADA catalyzes irreversible deamination of extracellular adenosine to inosine, than to hypoxanthine and xanthine finally oxidized to uric acid by xanthine oxidase (XO) in purine catabolic pathway, with generation of superoxide anions (Figure 1). If deamination is absent adenosine is rephosphorylated to 5'-AMP and ATP by adenosine kinase (12).

Therefore, compounds with XO and DPP-4 inhibitory potential will at the same time reduce $X O$ activity, as well as its substrates generation by suppressing formation of the complex between DPP-4 and ADA. 
<smiles>CC(C)C[C@H]1O[C@@H](COP(=O)(O)OP(=O)(O)OP(=O)(O)O)[C@@H](O)[C@@H]1OP(=O)(O)OC[C@H]1O[C@@H](n2cnc3c(N)ncnc32)[C@H](O)[C@@H]1O</smiles>

ATP

ADP

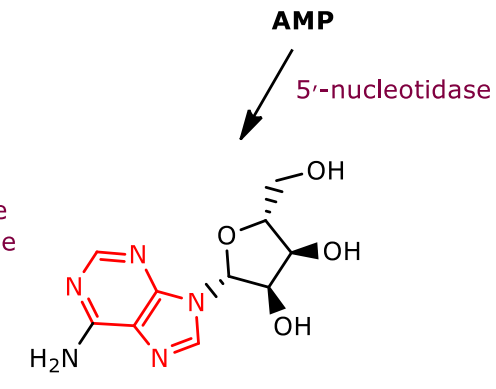

inosine

adenosine

inosine phosphorylase /<smiles>O=c1nc[nH]c2nc[nH]c12</smiles>

hypoxanthine

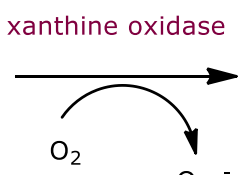

$\mathrm{O}_{2}$ dipeptidyl peptidase-4

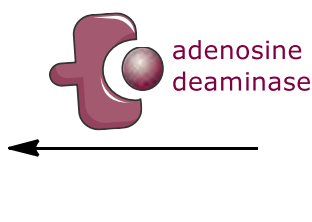

Figure 1. Schematic diagram of the irreversible deamination of adenosine to inosine, hypoxanthine and xanthine oxidized to uric acid (adapted from Lee et al. (12) and Xia et al. (9))<smiles>CC#CCn1c(N2CCC[C@H](N)C2)nc2c1c(=O)n(Cc1nc(C)c3ccccc3n1)c(=O)n2C</smiles>

Figure 2. Chemical structure of linagliptin

\section{Linagliptin, dipeptidyl peptidase-4 and} xanthine oxidase inhibitor

It has been shown that linagliptin, DPP-4 inhibitor with xanthine-based structure (Figure 2) and reported $\mathrm{IC}_{50}$ value of $\sim 1 \mathrm{nM}(13-16)$, at the oral dose of $5 \mathrm{mg} / \mathrm{kg}$ for 7 days normalized increased serum XO activity in septic rats (17). Additionally, linagliptin exerted an inhibitory effect on the activity of $\mathrm{XO}$ in vitro and in human serum derived from the healthy volunteer in a concentration-dependent manner up to $1 \mathrm{mM}$, as well as lowered uric acid levels in plasma of diabetic patients at the oral dose of 5 mg once daily for 24 weeks (18).

Generally, based on linagliptin as representative, DPP-4 inhibitors with purine-based scaffold may 
be hypothesized to exert hypouricemic effect via dual mechanism, inhibiting the activity of DPP-4 and its binding to ADA with subsequent increase of adenosine levels and decrease of availability of substrates for $\mathrm{XO}$, as well as inhibiting $\mathrm{XO}$ activity, with finally reduced production of uric acid.

\section{Overview of purine-based DPP-4 inhibitors}

Some DPP-4 inhibitors (13-16, 19-28) have been derived from a xanthine scaffold, similar to the structure of linagliptin (Table 1, Figure 3).

Table 1. DPP-4 inhibitors derived from purine scaffold with determined $\mathrm{IC}_{50}$ values from $0.05 \mathrm{nM}$ to $>24.50 \mu \mathrm{M}(13-16,19-23,25-27)$

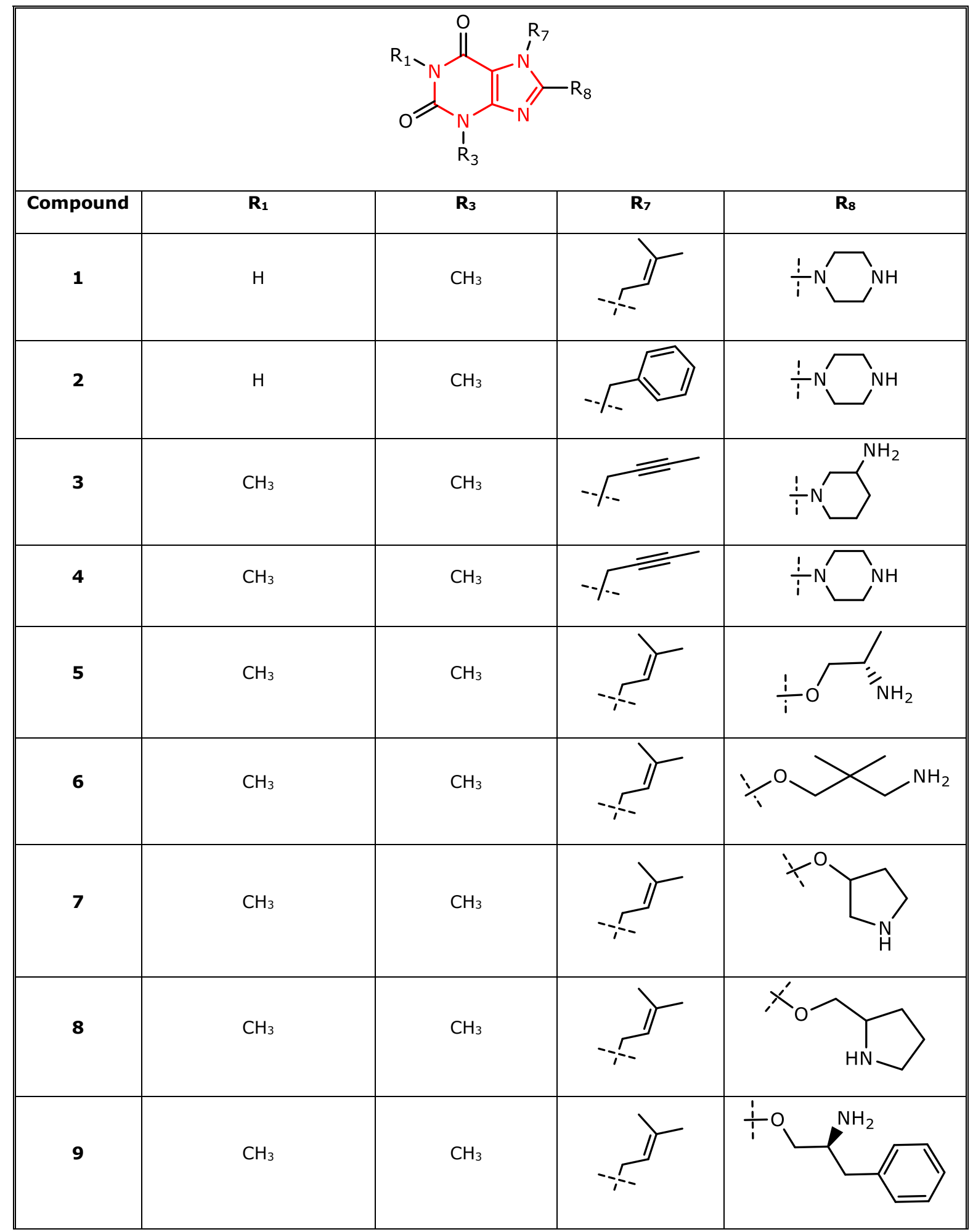




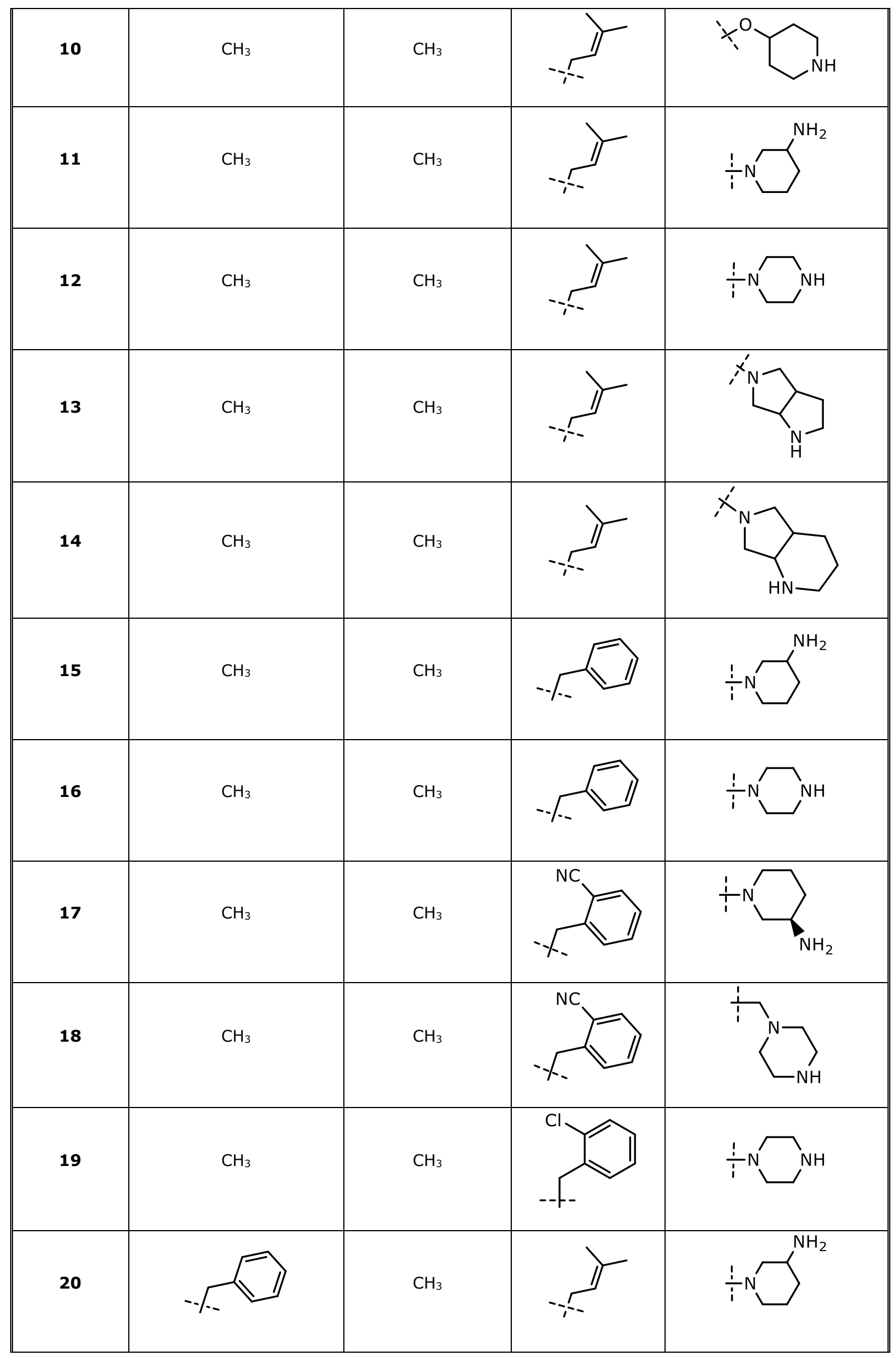




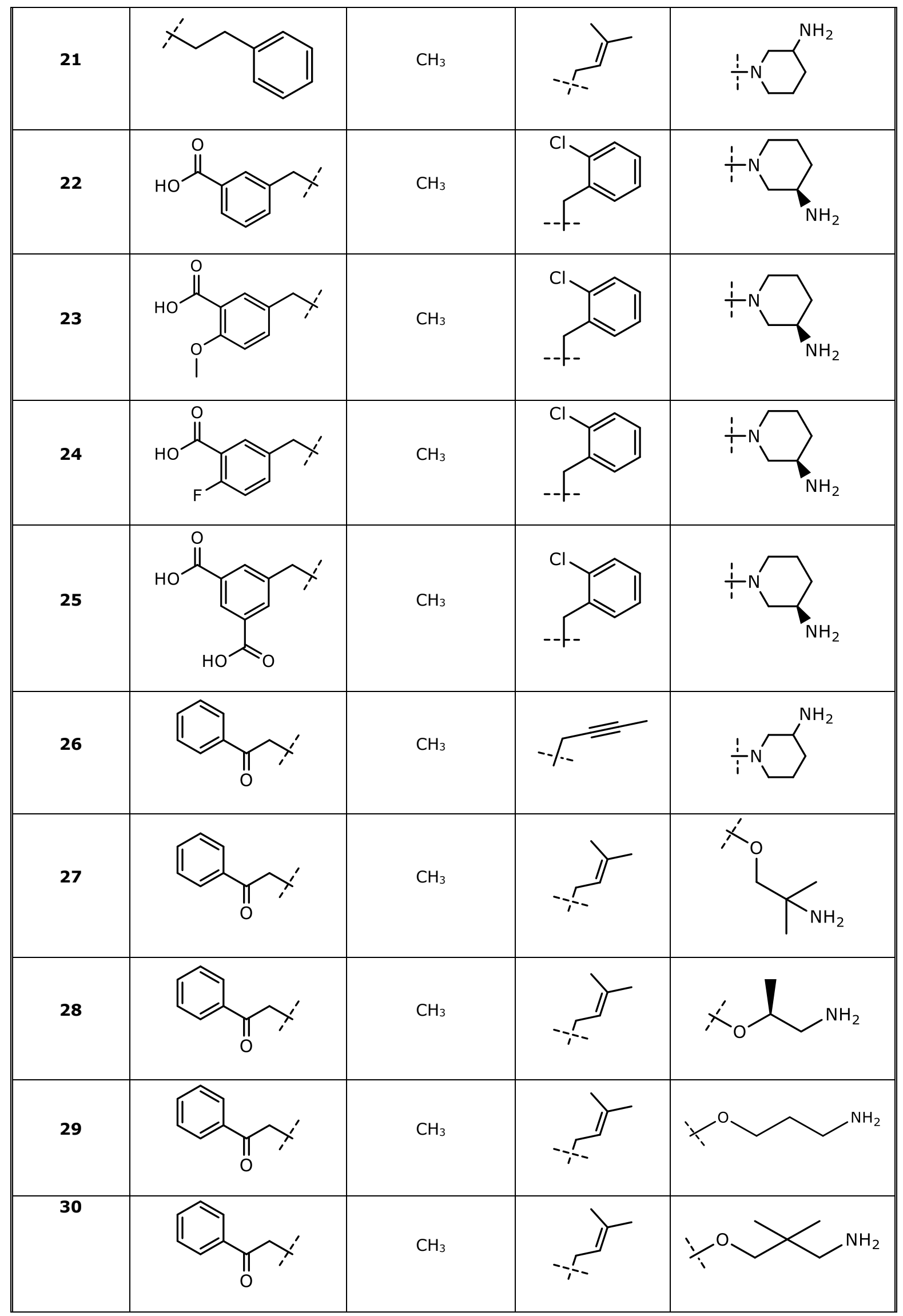




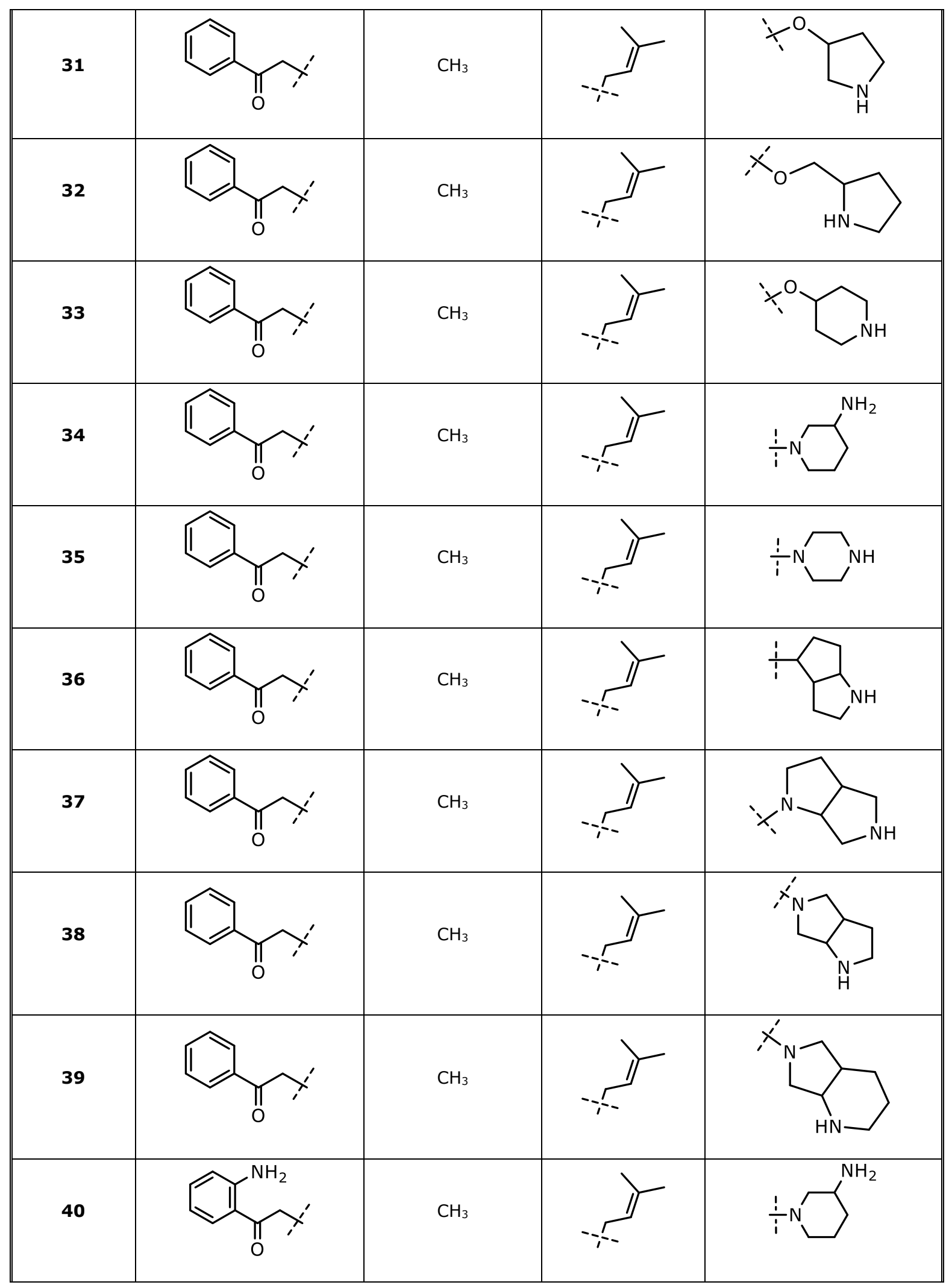




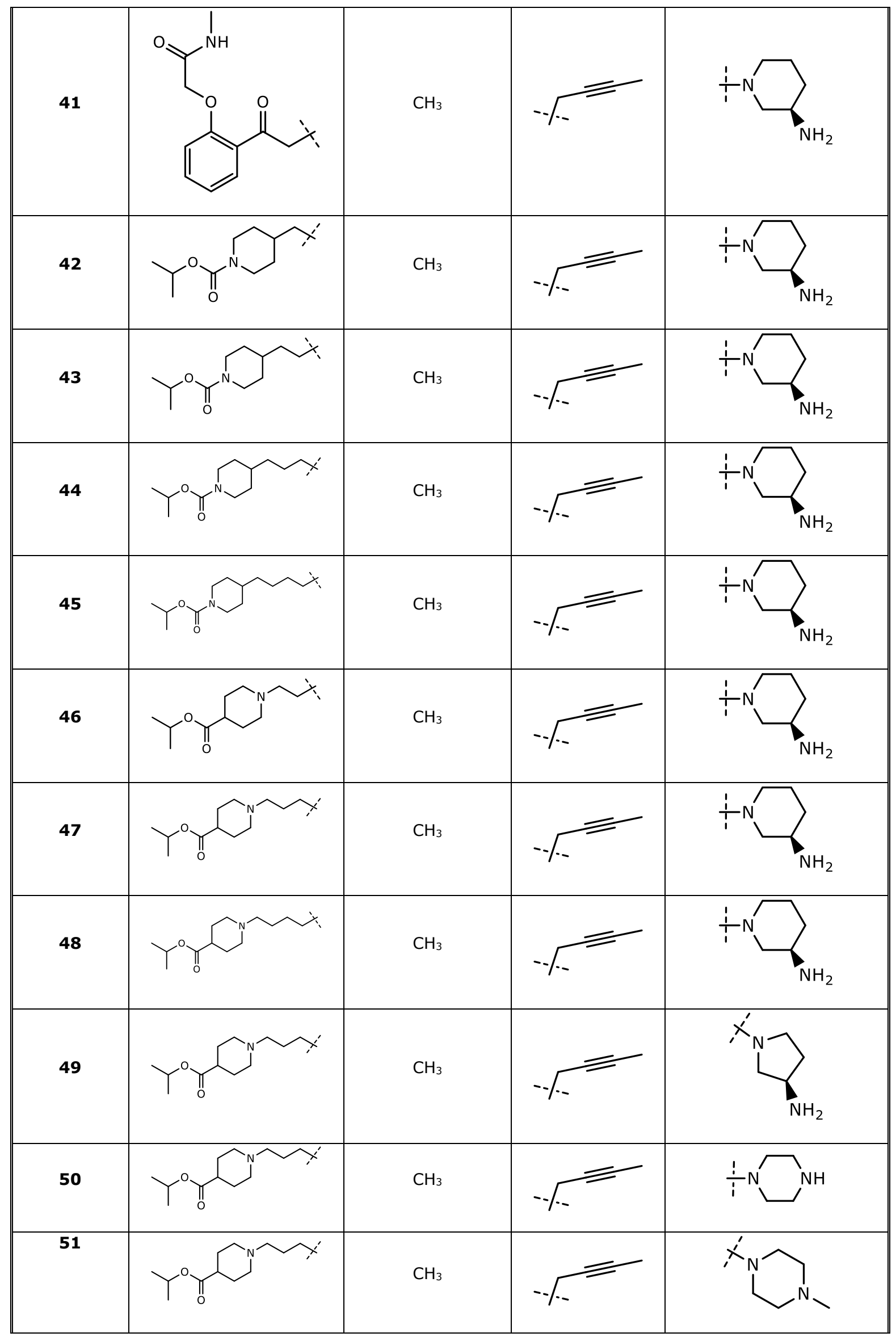




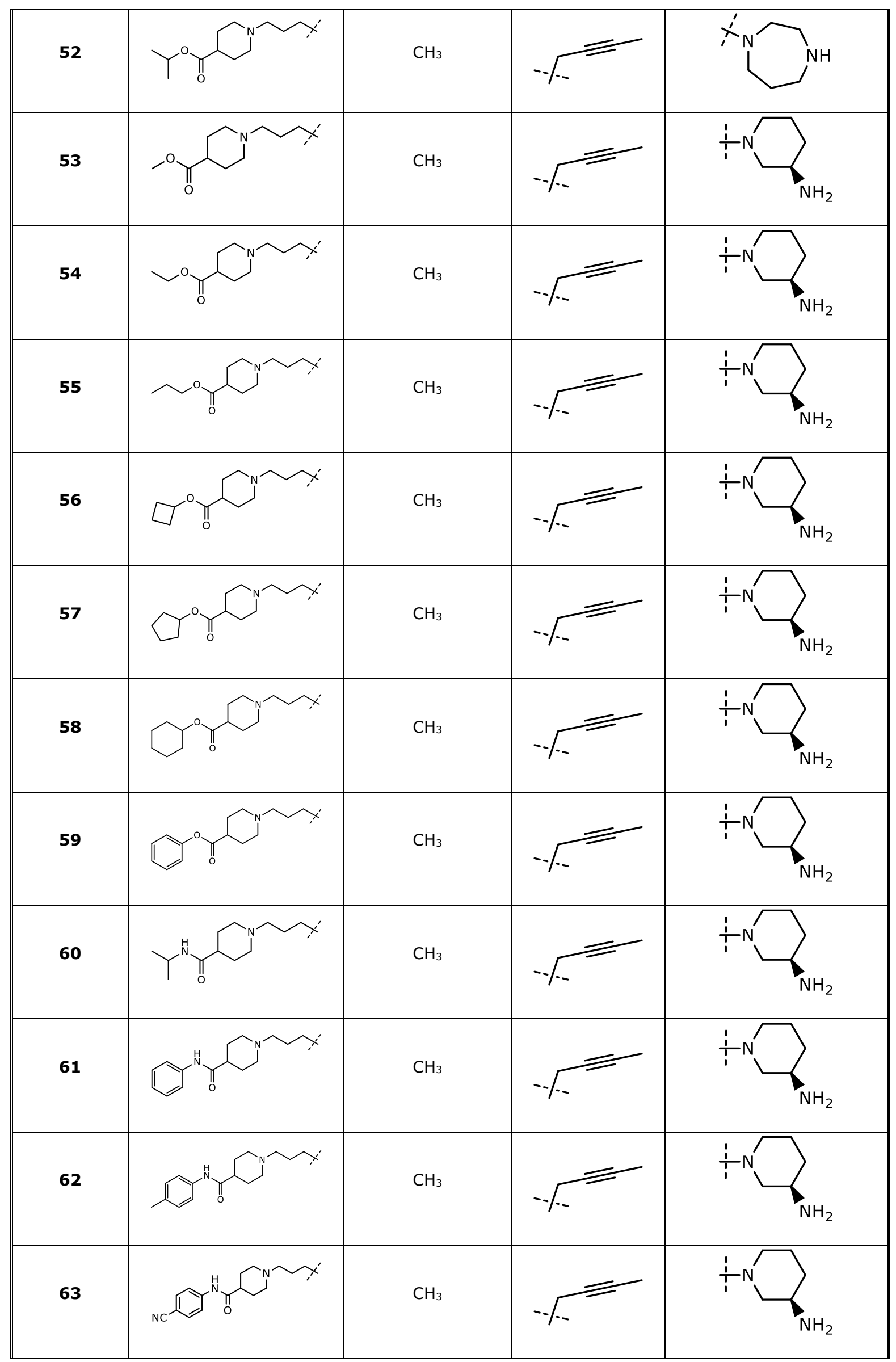




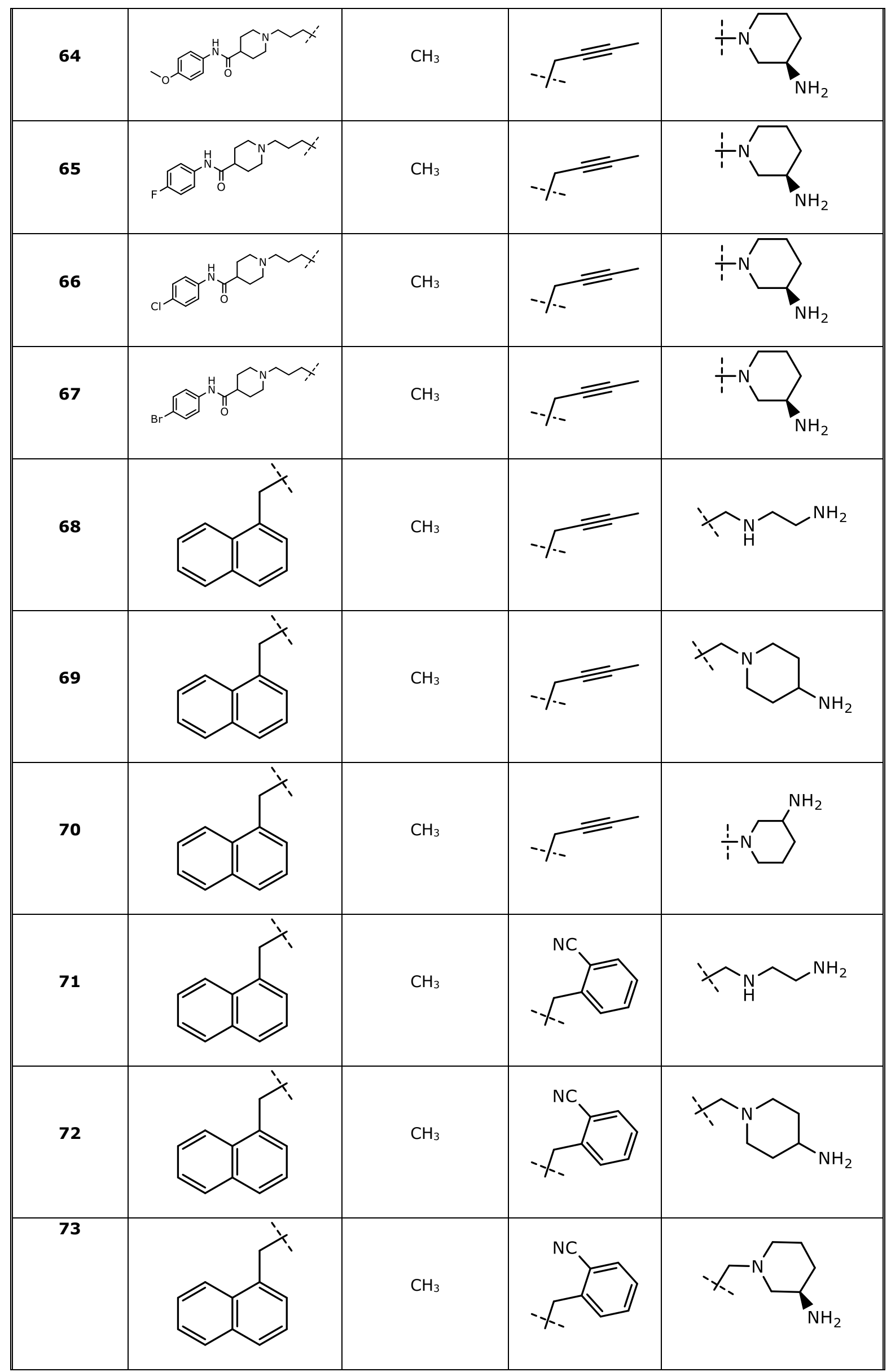




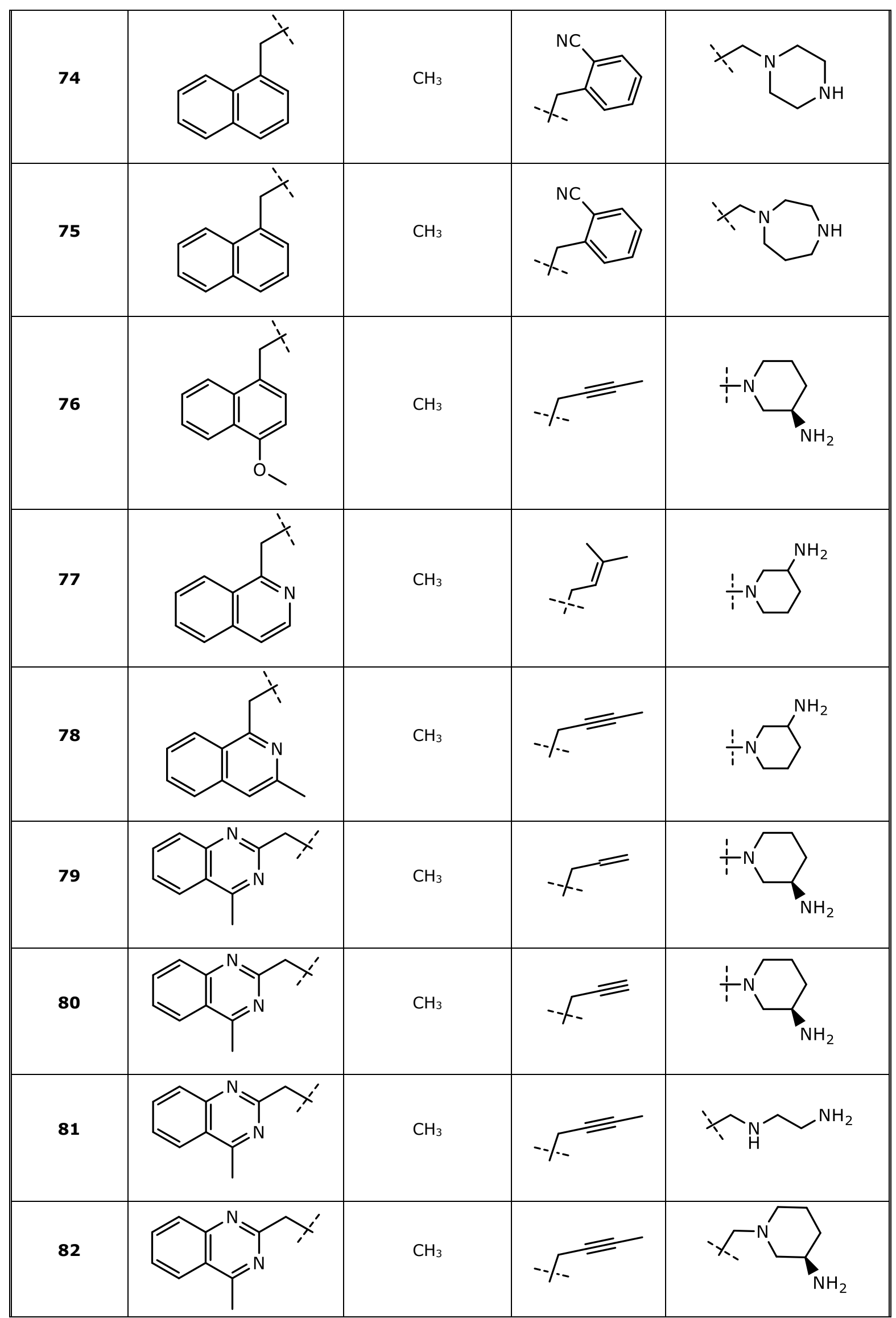




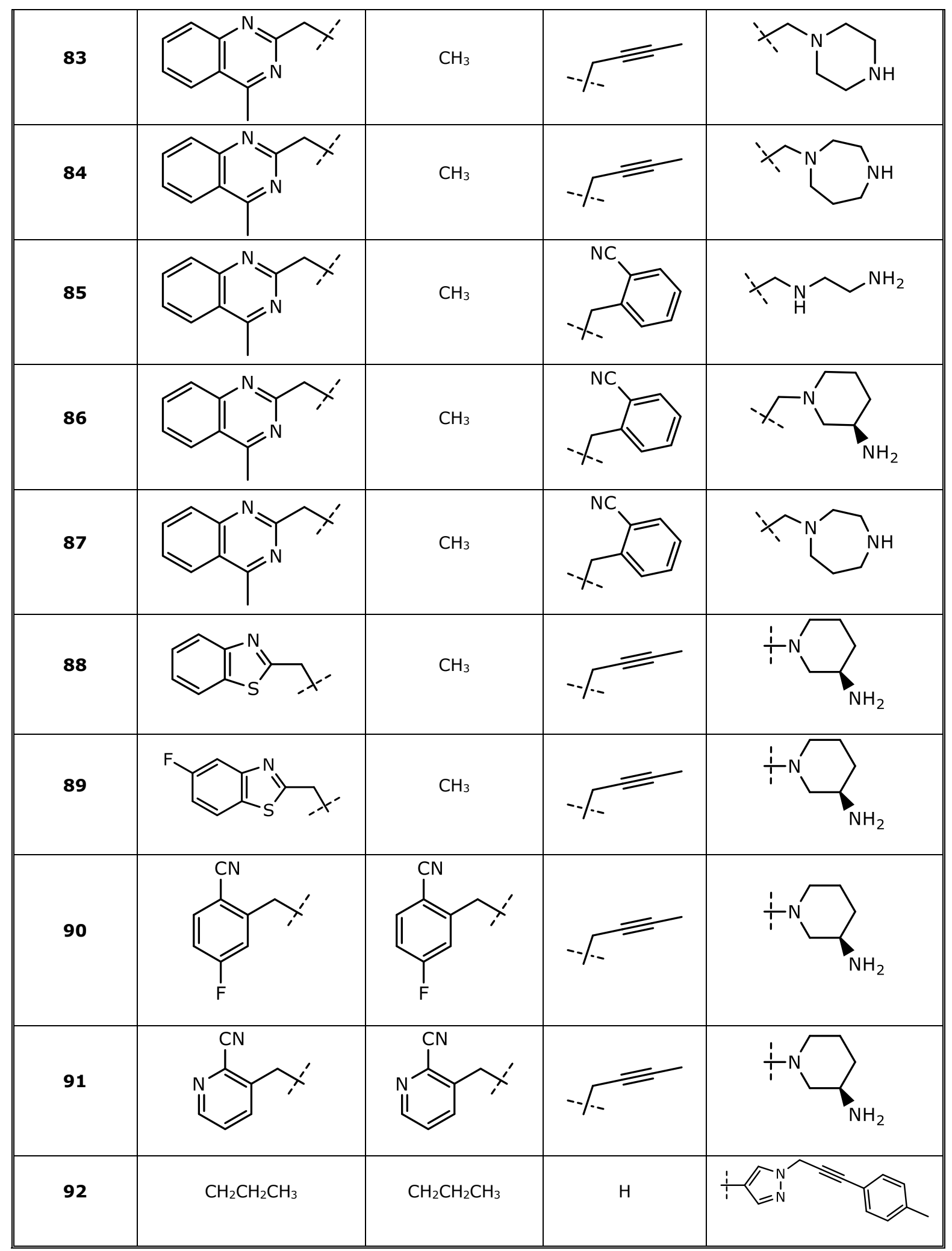


<smiles>Cn1c(=O)n(Cc2ccccc2C#N)c2c(N3CCC[C@H](N)C3)ncnc21</smiles>

93<smiles>CC#CCn1c(=O)n(-c2ccc(OC)nc2)c2ncnc(N3CCNCC3)c21</smiles>

94<smiles>CC#CCn1c(N2CCC[C@@H](N)C2)nc2c1c(=O)n(CC1=NC(C)(Cc3nc(Cn4c(=O)c5c(nc(N6CCC[C@@H](N)C6)n5CC#CC)n(C)c4=O)nc4ccccc34)c3ccccc3N1)c(=O)n2C</smiles>

95

Figure 3. DPP-4 inhibitors with purine scaffold structurally little different from the above listed representatives with reported $\mathrm{IC}_{50}$ values of $10 \mathrm{nM}, 89 \mathrm{nM}$ and $6 \mathrm{pM}$, respectively $(21,24,28)$

\section{Conclusion}

Besides XO activity, the availability of its substrates, affected by modulation of ADA activity, determine production of uric acid, and potential multitarget hypouricemic agents might offer a beneficial therapeutic approach. Based on evidenced linagliptin inhibitory potential on DPP-4 and $\mathrm{XO}$, the possibility of DPP-4 inhibitors with the purine-based scaffold to exert hypouricemic effect via the same dual mechanism like linagliptin exists. Although structures possess the same scaffold, position and type of substituents affect and determine the structure-activity relationship, and inhibitory potential of other purine- based DPP-4 inhibitors on XO remains to be experimentally assayed.

\section{Acknowledgments}

The financial support of this work by Ministry of Education, Science and Technological Development of the Republic of Serbia (Grants No. OI 172044 and TR 31060), Faculty of Medicine of the University of Niš (Internal project No. 4) is gratefully acknowledged. We thank L'Oréal Foundation for supporting the work in this paper through a fellowship to K. Tomovic.

\section{References}

1. Borghi C, Rosei EA, Bardin T, Dawson J, Dominiczak A, Kielstein JT, et al. Serum uric acid and the risk of cardiovascular and renal disease. J Hypertens 2015; 33(9):1729-41. [CrossRef] [PubMed]

2. Borghi C, Rodriguez-Artalejo F, De Backer G, Dallongeville J, Medina J, Nuevo J, et al. Serum uric acid levels are associated with cardiovascular risk score: A post hoc analysis of the EURIKA study. Int J Cardiol 2018; 253:167-73. [CrossRef] [PubMed]
3. Sharaf El Din UAA, Salem MM, Abdulazim DO. Uric acid in the pathogenesis of metabolic, renal, and cardiovascular diseases: A review. J Adv Res 2017; 8(5):537-48. [CrossRef] [PubMed]

4. Filiopoulos V, Hadjiyannakos D, Vlassopoulos D. New insights into uric acid effects on the progression and prognosis of chronic kidney disease. Ren Fail 2012; 34(4):510-20. [CrossRef] [PubMed]

5. Zoppini G, Targher G, Chonchol M, Ortalda V, Abaterusso $C$, Pichiri I, et al. Serum uric acid levels and 
incident chronic kidney disease in patients with type 2 diabetes and preserved kidney function. Diabetes Care 2012; 35(1):99-104. [CrossRef] [PubMed]

6. Hahn K, Kanbay M, Lanaspa MA, Johnson RJ, Ejaz AA. Serum uric acid and acute kidney injury: a mini review. J Adv Res 2017; 8(5):529-36. [CrossRef] [PubMed]

7. Kutzing MK, Firestein BL. Altered uric acid levels and disease states. J Pharmacol Exp Ther 2008; 324(1):17. [CrossRef] [PubMed]

8. Xia $Y$, Zweier JL. Substrate control of free radical generation from xanthine oxidase in the postischemic heart. J Biol Chem 1995; 270(32):18797-803. [CrossRef] [PubMed]

9. Xia Y, Khatchikian G, Zweier JL. Adenosine deaminase inhibition prevents free radical-mediated injury in the postischemic heart. J Biol Chem 1996; 271 (17):1 0096-102. [CrossRef] [PubMed]

10. Abbott CA, McCaughan GW, Levy MT, Church WB, Gorrell MD. Binding to human dipeptidyl peptidase IV by adenosine deaminase and antibodies that inhibit ligand binding involves overlapping, discontinuous sites on a predicted $\beta$ propeller domain. Eur J Biochem 1999; 266(3):798-810. [CrossRef] [PubMed]

11. Weihofen WA, Liu J, Reutter W, Saenger W, Fan $\mathrm{H}$. Crystal structure of CD26/dipeptidyl-peptidase IV in complex with adenosine deaminase reveals a highly amphiphilic interface. J Biol Chem 2004; 279 (41): 43330-5. [CrossRef] [PubMed]

12. Lee TM, Chen WT, Yang CC, Lin SZ, Chang NC. Sitagliptin attenuates sympathetic innervation via modulating reactive oxygen species and interstitial adenosine in infarcted rat hearts. J Cell Mol Med 2015; 19 (2):418-29. [CrossRef] [PubMed]

13. Ikuma $Y$, Hochigai $H$, Kimura $H$, Nunami $N$, Kobayashi $\mathrm{T}$, Uchiyama $\mathrm{K}$, et al. Discovery of $3 \mathrm{H}$-imidazo[4,5c]quinolin-4(5H)-ones as potent and selective dipeptidyl peptidase IV (DPP-4) inhibitors. Bioorg Med Chem 2012; 20(19):5864-83. [CrossRef] [PubMed]

14. Eckhardt $M$, Langkopf $E$, Mark $M$, Tadayyon $M$, Thomas L, Nar H, et al. 8-(3- $(R)$-aminopiperidin-1-yl)7-but-2-ynyl-3-methyl-1-(4-methyl-quinazolin-2ylmethyl)-3,7-dihydropurine-2,6-dione (BI 1356), a highly potent, selective, long-acting, and orally bioavailable DPP-4 inhibitor for the treatment of type 2 diabetes. J Med Chem 2007; 50(26):6450-3. [CrossRef] [PubMed]

15. Lin K, Cai Z, Wang F, Zhang W, Zhou W. Synthesis and biological evaluation of xanthine derivatives on dipeptidyl peptidase 4. Chem Pharm Bull 2013; 61 (4):477-82. [CrossRef] [PubMed]

16. Lai ZW, Li C, Liu J, Kong L, Wen X, Sun H. Discovery of highly potent DPP-4 inhibitors by hybrid compound design based on linagliptin and alogliptin. Eur J Med Chem 2014; 83:547-60. [CrossRef] [PubMed]

17. Kröller-Schön $S$, Knorr $M$, Hausding $M$, Oelze $M$, Schuff A, Schell R, et al. Glucose-independent impro- vement of vascular dysfunction in experimental sepsis by dipeptidyl-peptidase 4 inhibition. Cardiovasc Res 2012; 96(1):140-9. [CrossRef] [PubMed]

18. Yamagishi SI, Ishibashi Y, Ojima A, Sugiura T, Matsui T. Linagliptin, a xanthine-based dipeptidyl peptidase-4 inhibitor, decreases serum uric acid levels in type 2 diabetic patients partly by suppressing xanthine oxidase activity. Int J Cardiol 2014; 176(2):550-2. [CrossRef] [PubMed]

19. Czechtizky W, Dedio J, Desai B, Dixon K, Farrant E, Feng $Q$, et al. Integrated synthesis and testing of substituted xanthine based DPP4 inhibitors: application to drug discovery. ACS Med Chem Lett 2013; 4(8):76872. [CrossRef] [PubMed]

20. Zhang Z, Wallace MB, Feng J, Stafford JA, Skene RJ, Shi $L$, et al. Design and synthesis of pyrimidinone and pyrimidinedione inhibitors of dipeptidyl peptidase IV. J Med Chem 2011; 54(2):510-24. [CrossRef] [PubMed]

21. Costante R, Stefanucci A, Carradori S, Novellino E, Mollica A. DPP-4 inhibitors: a patent review (20122014). Expert Opin Ther Pat 2015; 25(2):209-36. [CrossRef] [PubMed]

22. Mo DW, Dong S, Sun H, Chen JS, Pang JX, Xi BM, et al. Synthesis and potent inhibitory activities of carboxybenzyl-substituted 8-(3-(R)-aminopiperidin-1yl)-7-(2-chloro/cyanobenzyl)-3-methyl-3,7-dihydropurine-2,6-diones as dipeptidyl peptidase IV (DPP-IV) inhibitors. Bioorg Med Chem Lett 2015; 25(9):1872-5. [CrossRef] [PubMed]

23. Chyan YJ, Chuang LM. Dipeptidyl peptidase-IV inhibitors: an evolving treatment for type 2 diabetes from the incretin concept. Recent Pat Endocr Metab Immune Drug Discov 2007; 1(1):15-24. [CrossRef]

24. Gupta R, Walunj SS, Tokala RK, Parsa KVL, Singh SK, Pal M. Emerging drug candidates of dipeptidyl peptidase IV (DPP IV) inhibitor class for the treatment of type 2 diabetes. Curr Drug Targets 2009; 10(1):7187. [CrossRef] [PubMed]

25. Augustyns K, Van der Veken P, Senten K, Haemers A. The therapeutic potential of inhibitors of dipeptidyl peptidase IV (DPP IV) and related proline-specific dipeptidyl aminopeptidases. Curr Med Chem 2005; 12 (8):971-98. [CrossRef] [PubMed]

26. Li G, Huan Y, Yuan B, Wang J, Jiang Q, Lin Z, et al. Discovery of novel xanthine compounds targeting DPP-IV and GPR119 as anti-diabetic agents. Eur J Med Chem 2016; 124:103-16. [CrossRef] [PubMed]

27. Eckhardt M, Hauel N, Himmelsbach F, Langkopf E, Nar $\mathrm{H}$, Mark M, et al. 3,5-Dihydro-imidazo [4, 5-d] pyridazin-4-ones: a class of potent DPP-4 inhibitors. Bioorg Med Chem Lett 2008; 18(11):3158-62. [CrossRef] [PubMed]

28. Shu C, Ge H, Song M, Chen JH, Zhou H, Qi Q, et al. Discovery of imigliptin, a novel selective DPP-4 inhibitor for the treatment of type 2 diabetes. ACS Med Chem Lett 2014; 5(8):921-6.

[CrossRef] [PubMed] 


\title{
POTENCIJALNO DUALNI MEHANIZAM HIPOURIKEMIJSKE AKTIVNOSTI DPP-4 INHIBITORA PURINSKE STRUKTURE
}

\author{
Katarina Tomović ${ }^{,}$Gordana Kocić 2 , Andrija Šmelcerović3
}

\author{
${ }^{1}$ Univerzitet u Nišu, Medicinski fakultet, Katedra za farmaciju, Niš, Srbija \\ ${ }^{2}$ Univerzitet u Nišu, Medicinski fakultet, Katedra za biohemiju, Niš, Srbija \\ ${ }^{3}$ Univerzitet u Nišu, Medicinski fakultet, Katedra za hemiju, Niš, Srbija \\ Kontakt: Andrija Šmelcerović \\ Bulevar dr Zorana Đinđića 81, 18000, Niš, Srbija \\ E-mail: a.smelcerovic@yahoo.com
}

Dipeptidil peptidaza-4 vezuje adenozin deaminazu, pri čemu nastaje kompleks koji katalizuje ireverzibilnu deaminaciju ekstracelularnog adenozina u inozin, što vodi generisanju hipoksantina i ksantina do mokraćne kiseline ksantin-oksidazom u katabolizmu purina uz produkciju reaktivnih kiseoničnih vrsta. Inhibitor dipeptidil peptidaze-4 ksantinske strukturne osnove, linagliptin, pokazao je inhibitorni potencijal na ksantin-oksidazi. Linagliptin pokazuje hipourikemijski efekat inhibiranjem aktivnosti dipeptidil peptidaze-4 i formiranja kompleksa ove proteaze i adenozin deaminaze, što uzrokuje porast sadržaja adenozina i smanjenu raspoloživosti supstrata ksantin-oksidaze, kao i inhibiranjem aktivnosti ksantin-oksidaze. Usled dokaza o dualnom mehanizmu hipourikemijske aktivnosti linagliptina, postoji mogućnost da drugi inhibitori dipeptidil peptidaze-4 purinske strukture pokazuju istu aktivnost.

Acta Medica Medianae 2019;58(1):50-63.

Ključne reči: dipeptidil peptidaza-4, ksantin-oksidaza, adenozin deaminaza 